\title{
PENGARUH PENAMBAHAN HIDROKOLOID LAMBDA KARAGENAN TERHADAP MUTU MIKROBIOLOGIS ROTI SELAMA PENYIMPANAN
}

\author{
[The effect of lambda carragenan hydricolloid addition on microbiological quality of bread during \\ storage]
}

\section{Moegiratul Amaro*, Mutia Devi Ariyana, Wiharyani Werdiningsih, Baiq Rien Handayani, Nazaruddin, Sri Widyastuti}

Program Studi IImu dan Teknologi Pangan, Fakultas Teknologi Pangan dan Agroindustri, Universitas Mataram *Email: moegiratulamaro@unram.ac.id

Diterima 8 Januari 2018/ Disetujui 18 April 2018

\begin{abstract}
The purpose of this study was to examine the effect of lambda carragenan addition as a natural food additive alternative to bread to improve microbiological quality and prolong the shelf life. The method used in this study was completely randomized design (CRD) with 7 days of storage at room temperature as treatment and repeated three times. Observed parameters was moisture content, total microbes, total fungi and total E.coli. The concentration of lambda carragenan used was $0.4 \%$. The observed data of water content was analyzed using Co-stat software with $5 \%$ significance Differences. If there was a real difference, then tested continued using Honestly Significance Differences (HSD) at level $5 \%$. Microbiological quality observation data (total microbes, total fungi and total coliform) were analyzed descriptively. The results showed that the storage of bread with the addition of $0.4 \%$ lambda carrageenan caused the bread to last for 4 days of storage. Water content of bread decreased during 7 days storage. The microbiological quality of bread indicates that the storage of bread for 4 days was still acceptable in accordance with Indonesian National Standard (SNI) with total microbial $8.556 \mathrm{log} \mathrm{cfu} / \mathrm{ml}$, total mushroom 4,255 log cfu / $\mathrm{ml}$, and amount of E.coli as much as <2,398 cfu / $\mathrm{ml}$. The types of fungi that grow on bread with the addition of lambda carrageenan wer Aspergillus niger and Aspergillus flavus.
\end{abstract}

Keywords: bread, hydrocolloid, lambda carrageenan, microbiological quality, shelf life

\begin{abstract}
ABSTRAK
Tujuan dari penelitian ini adalah untuk mengkaji pengaruh penambahan lambda karaginan sebagai alternative bahan tambahan makanan (BTM) alami pada roti untuk meningkatkan mutu mikrobiologi dan memperpanjang masa simpan. Metode yang digunakan pada penelitian ini adalah rancangan acak lengkap dengan perlakuan lama penyimpanan selama 7 hari pada suhu ruang dan diulang sebanyak tiga kali. Parameter yang diuji antara lain kadar air, total mikroba, total jamur dan total E.coli. Konsentrasi lambda karaginan yang digunakan adalah $0,4 \%$. Data hasil pengamatan kadar air dianalisis dengan software Co stat dengan taraf nyata $5 \%$. Apabila terdapat beda nyata, maka dilakukan uji lanjut menggunakan uji Beda Nyata Jujur (BNJ) pada taraf $5 \%$. Data hasil pengamatan mutu mikrobiologis (total mikroba, total jamur dan total koliform) dianalisis secara deskriptif. Hasil penelitian menunjukkan bahwa penyimpanan roti dengan penambahan $0,4 \%$ lambda karagenan menyebabkan roti bertahan selama 4 hari penyimpanan. Kadar air roti mengalami penurunan selama penyimpanan 7 hari. Mutu mikrobiologis roti menunjukkan bahwa penyimpanan roti selama 4 hari masih dapat diterima sesuai dengan Standar nasional Indonesia (SNI) dengan jumlah total mikroba 8,556 log cfu/ml, total jamur 4,255 log cfu/ml, dan jumlah E.coli sebanyak $<2,398 \mathrm{cfu} / \mathrm{ml}$. Jenis jamur yang tumbuh pada roti dengan penambahan lambda karagenan adalah Aspergillus niger dan Aspergillus flavus.
\end{abstract}

Kata kunci: Roti, hidrokoloid, lambda karaginan, mutu mikrobiologis, masa simpan

\section{PENDAHULUAN}

Roti adalah produk makanan yang terbuat dari tepung terigu dengan ragi atau bahan pengembang lainnya kemudian difermentasi dan dibakar (Setyo E, Noor L, 2004). Roti mempunyai berbagai macam jenis, salah satunya yaitu roti manis. Roti manis adalah roti yang mempunyai cita rasa manis yang menonjol, bertekstur empuk, diberi bermacam-macam isi dengan bentuk yang bervariasi. Roti termasuk makanan pokok karena kandungan karbohidratnya yang tinggi. Bahan baku yang digunakan dalam pembuatan roti yaitu tepung terigu, gula, susu, margarin, ragi, telur, garam, dan air. Sebagai bahan penunjang biasa ditambahkan essence dan obat-obatan roti yang dapat memperbaiki tekstur, aroma, dan cita rasa dari roti tersebut. Sebelum tahun 1950an roti hanya dibuat dari 
bahan dasar tepung terigu, telur, gula dan ragi roti dengan proses fermentasi selama 24 jam sehingga terjadi fermentasi sempurna yang menghasilkan roti yang bernilai gizi tinggi dengan rasa dan aroma yang lezat. Namun produksi roti secara komersil akan lebih mempertimbangkan aspek keuntungan dibandingkan dengan aspek keamanan pangan. Berbagai jenis bahan tambahan makanan (BTM) diperlukan untuk mendapatkan roti yang memenuhi tuntutan konsumen.

Roti termasuk makanan yang mudah rusak dengan masa simpan 3-4 hari. Kerusakan roti disebabkan oleh rusaknya protein dan pati, secara langsung kerusakan roti disebabkan oleh jamur. Pada saat penyimpanan, roti akan mengalami beberapa kerusakan jika disimpan terlalu lama atau tidak disimpan ditempat yang tepat. Kerusakan roti meliputi kerusakan fisik roti, misalnya mengerasnya tekstur, tumbuhnya jamur, dan ketengikan. Jamur yang paling sering ditemukan dalam roti adalah Rhizopus stolonifer, Penicillium expansum, $P$. Stoloniferum, Aspergillus niger, Neurosporasitophila, Mucor sp dan Geothricum $s p$. Pertumbuhan jamur ini berasal dari udara selama pendinginan roti, penanganan, pembungkusan atau dari alat pemotong.

Bahan tambahan makanan atau dikenal juga dengan istilah food additive yang biasa ditambahkan dapat berupa agensia pengembang, pemutih, pengoksidasi, pereduksi, enzim, pengemulsi dan pengawet. Bahan pengawet umumnya digunakan untuk memperpanjang masa simpan bahan makanan yang mempunyai sifat mudah rusak. Bahan ini dapat menghambat atau memperlambat proses degradasi bahan pangan terutama yang disebabkan oleh faktor biologi. Penggunaan pengawet dalam makanan harus tepat, baik jenis maupun dosisnya. Suatu bahan pengawet mungkin efektif untuk mengawetkan makanan tertentu, tetapi tidak efektif untuk mengawetkan makanan lainnya karena makanan mempunyai sifat yang berbeda-beda sehingga mikroba perusak yang akan dihambat pertumbuhannya juga berbeda. Beberapa bahan pengawet yang umum digunakan adalah benzoat, nitrit, nitrat, sorbat, sulfit dan propionat.

Produsen roti sering kali menambahkan BTM sintetis yang berbahaya bagi kesehatan konsumen diantaranya ialah potasium bromate (E 924) dan calcium propionate. Calcium propionat dengan takaran yang berlebih seringkali ditambahkan oleh produsen roti sebagai penghambat pertumbuhan jamur sehingga dapat memperpanjang daya simpan roti. Bahan kimia ini pada anak-anak dapat menimbulkan Attention-Defisit Hyperactivity Disorder (ADHD) yang menyebabkan seorang anak menjadi hiperaktif dan sulit berkonsentrasi.

Meningkatnya kesadaran masyarakat akan produk makanan yang aman bagi kesehatan telah mendorong penelitian tentang potensi penggunaan bahan non sintetis pada proses pengolahan makanan. Penelitian tentang potensi bahan tambahan alami atau non-sintetik yang aman serta dapat memperbaiki sifat adonan dan memperpanjang masa simpan produk roti juga telah mulai dilakukan. Salah satunya adalah penggunaan hidrokoloid. Penggunaan hidrokoloid dapat memperbaiki sifat adonan dan memperpanjang umur simpan roti dengan memperbaiki tekstur (Rodge et al., 2012) dan meningkatkan kemampuan daya ikat air adonan (Mandala et al., 2007).

Salah satu jenis hidrokoloid yang dapat digunakan adalah karaginan. Karaginan yang merupakan hidrokoloid hasil ektraksi dari rumput laut merah diketahui mempunyai sifat yang sangat baik untuk menahan air dalam bahan pangan (Cindy, 2006). Menurut Rosel et al., (2001) karaginan memiliki karakteristik yang baik untuk digunakan sebagai bread improver karena dapat menghasilkan volume adonan yang lebih besar dan crumb yang lebih lembut. Keunggulan lain dari karaginan adalah hidrokoloid jenis ini mampu menghambat proses staling dan pertumbuhan jamur pada roti (September. 2007; Fennema, 1996; Sciarini et al., 2012). Berdasarkan penelitian Widyastuti dkk, (2015), penambahan 0,4\% lambda karaginan mampu menghasilkan roti dengan volume pengembangan tertinggi, mempertahankan elastisitas dengan menghambat penurunan kadar air selama 96 jam masa simpan, menghasilkan crumb roti yang lembab dan lembut serta memiliki pori yang seragam dan berukuran kecil. Kappa karaginan menghasilkan roti dengan kualitas terbaik pada konsentrasi $0,6 \%$. Penelitian ini secara khusus bertujuan untuk mengetahui pengaruh penambahan lambda karaginan terhadap mutu mikrobiologis roti dan daya simpannya.

\section{Bahan dan Alat}

\section{METODOLOGI}

Bahan yang digunakan pada penelitian ini antara lain lambda karaginan. Bahan 
pembuatan roti diantaranya tepung terigu protein tinggi, gula, susu, kuning telur, ragi (fermipan), air, mentega dan garam. Bahan pengujian mikrobiologis diantaranya media Potato Dextrose Agar (PDA) untuk analisis total jamur, medium Plate Count Agar (PCA) untuk analisis total mikroba, medium Violet Red Bile Agar (VRBA) untuk analisis total koliform, larutan buffer phosphate, $\mathrm{HCl}$, aquades dan plastik OPP dengan ukuran $12 \mathrm{~cm}$ x $17 \mathrm{~cm}+4 \mathrm{~cm}$ (untuk lipatan dan lem) dan ketebalan 0,32 mikron.

Alat yang digunakan dalam proses ekstraksi karaginan antara lain: timbangan, gunting, kompor, panci stainless steel, pengaduk kayu, kain saring, beaker glass, gelas ukur, loyang kaca dan oven.

Alat yang digunakan dalam proses pembuatan roti antara lain: timbangan, bread maker, piring, baskom, sendok, cetakan aluminium, loyang, kuas mentega, dan oven.

Alat yang digunakan dalam proses uji mikrobiologis adalah erlenmeyer, beaker glass, hot plate, magnetic stirer, autoclave, label, bunsen, timbangan analitik, plastik steril, pinset/gunting, stomacher, rak tabung reaksi, tabung reaksi, petridish, colony counter, waterbath, mikroskop, inkubator $37 \pm 1^{\circ} \mathrm{C}$, dan pipet mikro.

\section{Persiapan}

\section{Proses Pembuatan Roti}

Dilakukan penimbangan semua bahan sesuai dengan formulasi telah ditentukan. Dilakukan pencampuran bahan-bahan seperti tepung terigu protein tinggi, gula pasir, ragi, bread improver serta susu bubuk. Diaduk dengan menggunakan mixer dengan menggunakan kecepatan rendah sampai tercampur rata. Dimasukkan telur lalu air sedikit demi sedikit sampai membentuk gumpalan-gumpalan. Setelah air tercampur, masukan margarin dan garam dengan kecepatan rendah selama 2 menit, kemudian ubah ke kecepatan sedang dan aduk hingga adonan kalis. Dilakukan fermentasi awal dengan cara membulatkan adonan (rounding) dan ditutup plastik selama 10 menit. Dilakukan pencetakan adonan berbentuk bulat. Dilakukan fermentasi akhir/final proofing dengan cara ditutup kain tetapi jangan sampai penutupnya menyentuh permukaan roti sampai adonan mengembang hingga 90\%. Fermentasi akhir roti dapat dilakukan di suhu kamar. Pemolesan roti manis sebelum dibakar dengan menggunakan bahan telur dan susu cair yang telah tercampur dan dipoles dengan alat kuas. Pengovenan dengan suhu oven 160$180^{\circ} \mathrm{C}$ dan panggang selama 60 menit. Proses ini disebut juga dengan istilah Baking.

\section{Parameter Penelitian \\ 1. Kadar air}

Metode untuk analisa kadar air yang digunakan dalam penelitian ini yaitu metode Oven (Thermogravimetri) (Sudarmadji, Haryono dan Suhardi, 1997), Adapun prosedur dalam metode oven adalah sebagai berikut : Ditimbang bahan yang telah dihaluskan sebanyak 3 gram dalam botol timbang yang telah diketahui beratnya. Dikeringkan dalam oven pada suhu $105^{\circ} \mathrm{C}$ selama 4 jam. Kemudian didinginkan dalam eksikator selama 15 menit dan ditimbang. Dipanaskan lagi dalam oven 1 jam, dinginkan dalam eksikator dan ditimbang. Perlakuan ini diulang sampai tercapai berat konstan (selisih penimbangan berturut-turut kurang dari 0,2 mg). Pengurangan berat merupakan banyaknya air dalam bahan.

Kadar air $=\frac{\text { berat awal-berat akhir }}{\text { berat awal }} \times 100 \%$

\section{Total Jamur}

Metode yang digunakan untuk analisis total jamur adalah cawan agar tuang (pour plate method). Adapun tahapan penentuan total jamur adalah sebagai berikut: Alat -alat yang digunakan disterilkan dalam oven pada suhu $170^{\circ} \mathrm{C}$ selama 2 jam. Sampel ditimbang secara aseptis sebanyak 5 gram. Media ditimbang seberat 3,5 gram (untuk pengujian 1 sampel), kemudian media dimasukkan ke dalam erlenmeyer yang berisi $200 \mathrm{ml}$ aquades. Media dipanaskan pada hot plate yang dilengkapi dengan magnetic stirer sampai larutan menjadi jernih. Sampel yang sudah ditimbang dimasukkan ke dalam plastik steril yang sudah berisi larutan Buffer Phosphate (BF) sebanyak $45 \mathrm{ml}$, kemudian dihomogenkan pada alat stomacher. Sampel dan larutan BF yang sudah homogen, diambil sebanyak $1 \mathrm{ml}$ dengan menggunakan pipet steril lalu masukkan ke dalam tabung reaksi yang berisi $9 \mathrm{ml} \mathrm{BF}\left(10^{-2}\right)$, kemudian diambil 1 $\mathrm{ml}$ dari pengenceran $10^{-2}$ dan dimasukkan ke dalam tabung reaksi yang berisi larutan BF sebanyak $9 \mathrm{ml}\left(10^{-3}\right)$.

Dituangkan $15 \mathrm{ml}-20 \mathrm{ml}$ media agar kedalam cawan-cawan petri steril dan dinginkan. Pipet $0,1 \mathrm{ml}$ dari setiap pengenceran $\left(10^{-1}, 10^{-2}, 10^{-3}\right)$ kedalam cawan petri yang telah berisi media diatas dan diratakan dengan menggunakan batang gelas bengkok. Dilakukan secara duplo untuk setiap 
pengenceran. Supaya sampel meresap kedalam media agar diamkan sekurang kurangnya 1 jam. Di inkubasi cawan-cawan tersebut dalam posisi terbalik dalam inkubator pada suhu $37^{\circ} \mathrm{C}$ selama 48 jam. Jumlah koloni jamur yang dihitung pada cawan petri adalah 15-150 koloni. Cara perhitungan koloni jamur adalah menggunakan rumus sebagai berikut :

Total Koloni $(\mathrm{CFU} / \mathrm{g})=$ Jumlah koloni $\mathrm{x}$ $1 /$ (tingkat pengenceran)

\section{Total Mikroba}

Pengamatan untuk total mikroba dilakukan dengan memodifikasi metode tuang atau pour plate method (Fardiaz, 1992) dengan langkah-langkah sebagai berikut: Sampel roti yang telah dihancurkan sebanyak 1 gram diencerkan hingga pengenceran $10^{-6}$. Dipipet $1 \mathrm{ml}$ sampel dari pengenceran $10^{-4}, 10^{-}$ 5 , dan $10^{-6}$, kemudian dimasukkan kedalam cawan petri masing-masing secara duplo. Dituang medium PCA $\left(47-50^{\circ} \mathrm{C}\right)$ sebanyak $15-$ $20 \mathrm{ml}$ kemudian digoyang agar sampel menyebar. Didiamkan sampai agar membeku. Diinkubasi pada suhu $37^{\circ} \mathrm{C}$ selama 48 jam. Koloni pada cawan dihitung dengan kisaran jumlah 25-250 koloni.

\section{Total E. coli}

Pengamatan untuk total koliform dilakukan dengan memodifikasi metode tuang atau pour plate method (Fardiaz, 1992), dengan langkah-langkah sebagai berikur: Dari pengenceran $10^{-1}, 10^{-2}$, dan $10^{-3}$ dipipet sebanyak $1 \mathrm{ml}$ kedalam cawan petri secara duplo. Dituang kira-kira $10 \mathrm{ml}$ medium VRBA dan dibiarkan membeku. Diinkubasi secara terbalik pada suhu $370 \mathrm{C}$ selama 48 jam. Bakteri koliform akan membentuk koloni dengan ukuran diameter kira-kira 0,5 mm atau lebih besar, berwarna merah ungu, dikelilingi oleh areal yang menunjukkan pengendapan garam bile.

\section{Karakterisasi dan identifikasi isolat}

Isolat jamur dikarakterisasi berdasarkan pemeriksaan morfologi dengan makroskopik dan mikroskopik dan diidentifikasi dengan membandingkan karakteristiknya dengan karakteristik jamur yang telah diketahui.

\section{Rancangan Percobaan dan Analisis Data}

Metode yang digunakan pada penelitian ini adalah rancangan acak lengkap dengan perlakuan lama penyimpanan selama 7 hari pada suhu ruang dan diulang sebanyak
ISSN: 2443-1095

tiga kali ulangan sehingga diperoleh 21 unit percobaan. Parameter yang diuji antara lain kadar air, total mikroba, total jamur dan total koliform. Konsentrasi lambda karaginan yang digunakan adalah 0,4\%. Data hasil pengamatan kadar air dianalisis keragaman (analysis of Variance) pada taraf nyata 5\% menggunakan software Co-Stat. apabila terdapat beda nyata, maka dilakukan uji lanjut menggunakan uji Beda Nyata Jujur (BNJ) pada taraf 5\% (Hanafiah,2002). Data hasil pengamatan mutu mikrobiologis (total mikroba, total jamur dan total koliform) dianalisis secara deskriptif.

\section{HASIL DAN PEMBAHASAN}

\section{Kadar Air}

Hasil perhitungan kadar air, total jamur, total mikroba dan total coliform pada roti dengan penambahan lambda karaginan yang disimpan pada suhu kamar selama 7 hari (Tabel 1).

Tabel 1. Purata Hasil Pengamatan dan Uji Lanjut BNJ 5\% kadar air pada roti dengan penambahan lambda karaginan yang disimpan pada suhu ruang selama 7 hari

\begin{tabular}{cc}
\hline $\begin{array}{c}\text { Lama } \\
\text { penyimpanan } \\
\text { (hari) }\end{array}$ & Purata kadar air (\%) \\
\hline 0 & $33.003430465 \mathrm{a}$ \\
1 & $30.88982053 \mathrm{ab}$ \\
2 & $30.88216396 \mathrm{ab}$ \\
3 & $30.72340504 \mathrm{ab}$ \\
4 & $30.320982805 \mathrm{~b}$ \\
5 & $29.53061895 \mathrm{~b}$ \\
6 & $29.487935095 \mathrm{~b}$ \\
7 & $29.033320965 \mathrm{~b}$ \\
\hline
\end{tabular}

Ket: angka-angka yang diikuti oleh huruf-huruf yang sama pada kolom yang sama menunjukkan tidak ada perbedaan nyata pada taraf nyata $5 \%$

Tabel 1 menunjukkan bahwa penyimpanan roti selama 7 hari memberikan pengaruh yang berbeda nyata terhadap kadar air. Parameter kadar air roti berkisar antara $33,0034 \%$ sampai dengan 29,0333\%. Parameter kadar air menunjukkan roti dengan perlakuan penyimpanan selama 0 hari memberikan pengaruh yang berbeda nyata dengan roti yang disimpan selama 4 hari, 5 hari, 6 hari dan 7 hari.

Berdasarkan Tabel 1, dapat diamati bahwa kadar air roti dengan penambahan 
lambda karaginan mengalami penurunan selama 7 hari penyimpanan. Roti dengan penambahan karagenan memiliki kadar air yang cenderung lebih stabil. Menurut Ghanbari dan Farmani (2013), roti dengan penambahan hidrokoloid menunjukkan penurunan kadar air yang lebih rendah selama masa simpan sehingga menyebabkan berkurangnya laju dehidrasi pada crumb roti dan mencegah penurunan elastisitas roti. Kadar air yang tidak stabil terjadi pada roti yang tidak ditambahkan hidrokoloid selama masa simpan sehingga menyebabkan penurunan elastisitas yang cukup besar. Penurunan kadar air diketahui dapat mempercepat pembentukan ikatan silang antara pati dan protein yang menyebabkan roti menjadi keras dan tidak elastis (Raychaudhuri dan Chakraborty, 2013).

\section{Jumlah Total Mikroba}

Jumlah total mikroba pada roti dengan penambahan lambda karaginan mengalami peningkatan selama 7 hari penyimpanan (Tabel 2). Jumlah total mikroba pada hari ke-0 adalah <5,398 log CFU/ml Pada hari ke-1 penyimpanan, jumlah total mikroba meningkat menjadi 5,431 log CFU/ml demikian juga pada penyimpanan hari ke-2 jumlah total mikroba meningkat menjadi 6,771 log CFU/ml. Pada penyimpanan hari ke-5 hingga hari ke-7 jumlah total mikroba meningkat menjadi $>10,938 \log$ CFU/ml.

Tabel 2. Hasil Pengamatan total mikroba pada roti dengan penambahan lambda karaginan yang disimpan pada suhu ruang selama 7 hari

\begin{tabular}{crr}
\hline \multirow{2}{*}{$\begin{array}{c}\text { Lama } \\
\text { Penyimpanan } \\
\text { (hari) }\end{array}$} & \multicolumn{2}{c}{ Total Mikroba (log cfu/ml) } \\
\cline { 2 - 3 } & \multicolumn{1}{c}{ Kontrol } & \multicolumn{1}{c}{ Lambda } \\
\hline 0 & 5.255 & $<5.398$ \\
1 & 8.041 & 5.431 \\
2 & 6.771 & 6.771 \\
3 & $>8.398$ & 5.531 \\
4 & $>10.398$ & 8.556 \\
5 & $>10.398$ & $>10.398$ \\
6 & $>10.398$ & $>10.398$ \\
7 & $>10.398$ & $>10.398$ \\
\hline
\end{tabular}

Jumlah total mikroba roti dengan penambahan lambda karaginan pada hari ke-3 penyimpanan sebesar 5,531 log CFU/ml sedangkan roti tanpa penambahan karaginan memiliki total mikroba yang lebih tinggi yaitu lebih besar dari >8.398 log CFU/ml.

\section{Jumlah Total Jamur}

Pada pengamatan jumlah total jamur, roti dengan penambahan lambda karaginan mengalami peningkatan jumlah total jamur selama 7 hari penyimpanan (Tabel 3). Penyimpanan hari ke-0 hingga hari ke-3 memiliki total jamur sangat rendah yaitu $<3.176$ log CFU/ml. Pada penyimpanan hari ke4 jumlah total jamur meningkat menjadi 4,255 log CFU/ml. Semakin lama waktu penyimpanan, jumlah total jamur semakin besar. Pada penyimpanan hari ke- 6 total jamur mencapai 4,672 log CFU/ml dan pada hari ke-7 penyimpanan jumlah total jamur mencapai >3,176 log CFU/ml.

Tabel 3. Hasil Pengamatan total jamur pada roti dengan penambahan lambda karaginan yang disimpan pada suhu ruang selama 7 hari

\begin{tabular}{ccc}
\hline \multirow{2}{*}{$\begin{array}{c}\text { Lama } \\
\text { Penyimpanan } \\
\text { (hari) }\end{array}$} & \multicolumn{2}{c}{ Total Jamur (Log cfu/ml) } \\
\cline { 2 - 3 } & Kontrol & Lambda \\
\hline 0 & $<3.176$ & $<3.176$ \\
1 & $<3.176$ & $<3.176$ \\
2 & $<3.176$ & $<3.176$ \\
3 & $<3.176$ & $<3.176$ \\
4 & $<3.176$ & 4.255 \\
5 & 4.613 & 3.756 \\
6 & $>3.176$ & 4.672 \\
7 & $>3.176$ & $>3.176$ \\
\hline
\end{tabular}

Roti dengan penambahan lambda karaginan pada penyimpanan hari ke-4 memiliki total jamur yang lebih tinggi dibandingkan roti tanpa karaginan yaitu sebesar 4,255 log CFU/ml sedangkan kontrol memiliki total jamur $<3,176 \log \mathrm{CFU} / \mathrm{ml}$.

\section{Jumlah Total E. coli}

Roti dengan penambahan lambda karaginan memiliki jumlah E.coli yang rendah selama penyimpanan dari hari ke-0 hingga hari ke-7 yaitu <2,398 log CFU/ml (Tabel 4).

Tabel 4. Hasil Pengamatan jumlah E.coli pada roti dengan penambahan lambda karaginan yang disimpan pada suhu ruang selama 7 hari

\begin{tabular}{ccc}
\hline \multirow{2}{*}{$\begin{array}{c}\text { Lama } \\
\text { Penyimpanan } \\
\text { (hari) }\end{array}$} & \multicolumn{2}{c}{ E.coli ( Log cfu/ml) } \\
\cline { 2 - 3 } & Kontrol & Lambda \\
\hline 0 & $<2.398$ & $<2.398$ \\
1 & $<2.398$ & $<2.398$ \\
3 & $<2.398$ & $<2.398$ \\
4 & $<2.398$ & $<2.398$ \\
5 & $<2.398$ & $<2.398$ \\
6 & $<2.398$ & $<2.398$ \\
7 & $<2.398$ & $<2.398$ \\
& $<2.398$ & $<2.398$ \\
\hline
\end{tabular}


Hal ini menunjukkan bahwa baik alat, bahan ataupun pembuat roti bebas dari E.coli yang terdapat pada sumber air. Total E.coli roti dengan penambahan lambda karaginan ataupun tanpa penambahan karaginan sangat rendah yaitu $<2,398 \log \mathrm{CFU} / \mathrm{ml}$ selama 7 hari penyimpanan.

\section{Karakterisasi dan Identifikasi Isolat}

Roti sangat mudah mengalami kerusakan mikrobiologis terutama akibat pertumbuhan jamur. Berdasarkan hasil pengamatan roti selama masa simpan (Gambar 4) dan hasil inokulasi jamur pada medium PDA, pada roti kontrol terdapat 4 jenis jamur penyebab kerusakan yang berhasil diisolasi (Gambar 5), sedangkan pada roti dengan penambahan lambda karagenan hanya terdapat dua jenis jamur (Gambar 6). Data ini menunjukkan bahwa penambahan lambda karagenan mampu menekan pertumbuhan beberapa jenis jamur penyebab kerusakan pada roti. Hal ini sejalan dengan pernyataan September (2007) yang menyatakan bahwa lambda karagenan merupakan hidrokoloid yang mampu menghambat pertumbuhan jamur pada roti. Adapun senyawa bioaktif pada karagenan yang bersifat antagonis terhadap jamur belum dapat dikonfirmasi.

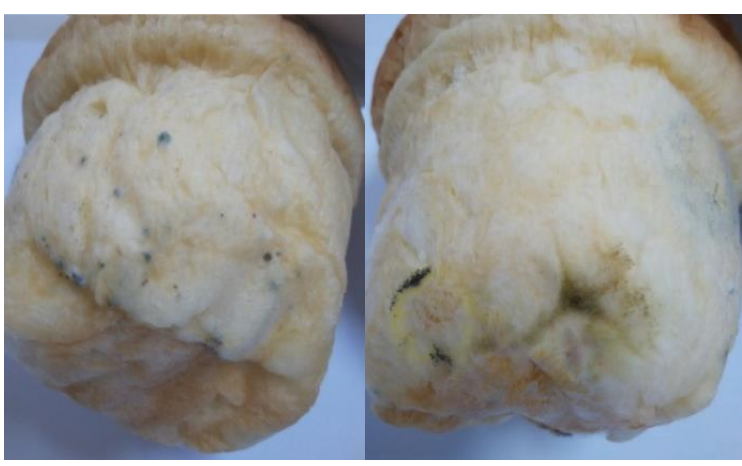

Gambar 4. Pengamatan Pertumbuhan Jamur pada Roti Selama Masa Simpan

Jenis jamur utama penyebab kerusakan pada roti diantaranya adalah Penicillium, Aspergillus, Monilia, Mucor, Endomyces, Cladosporium, Fusarium, and Rhizopus (Legan, 1993; Ponte et al., 1987 dalam Kam et al., 2007). Hasil analisis morfologi koloni jamur yang tumbuh pada medium PDA dan hasil pengamatan morfologi jamur secara mikroskopis menunjukkan bahwa 4 jenis jamur perusak pada roti kontrol dan roti dengan penambahan lambda karaginan terdiri dari Aspergillus niger, Aspergillus flavus dan 2 jenis Penicillium (Gambar 5).

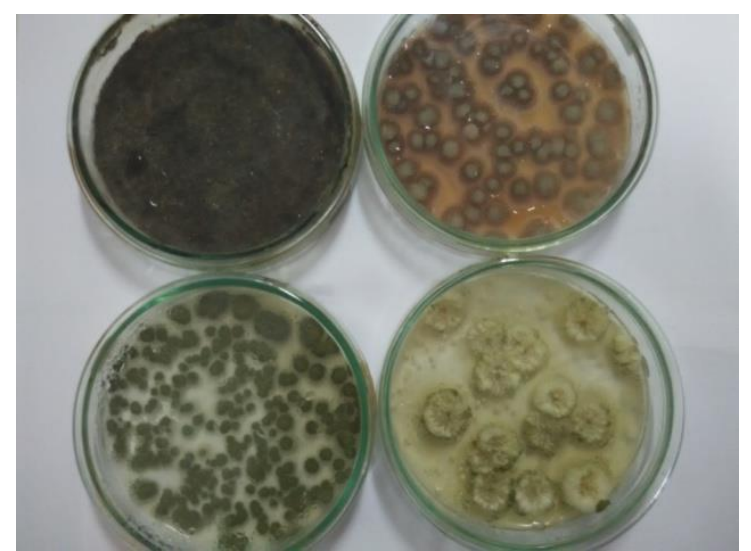

Gambar 5. Isolat Jamur Penyebab Kerusakan Roti Kontrol dan Roti dengan Penambahan Lambda Karagenan pada Medium PDA

Aspergillus flavus dan Aspergillus niger merupakan dua jenis Aspergillus yang dapat menyebabkan kerusakan pada makanan. Aspergillus niger teridentifikasi berdasarakan ciri-ciri spesifik yang dimiliki (Gambar 6) diantaranya adalah hifa septat dan miselium bercabang, konidiofora membengkak menjadi vesikel pada ujungnya, membawa sterigmata dimana tumbuh konidia dan konidia yang besar, bulat dan berwarna hitam atau coklathitam (Fardiaz, 1992). Aspergillus flavus teridentifikasi dengan ciri yang serupa dengan Aspergilus niger hanya memiliki perbedaan pada warna konidia yang berwarna kuning kecoklatan (Gambar 6).

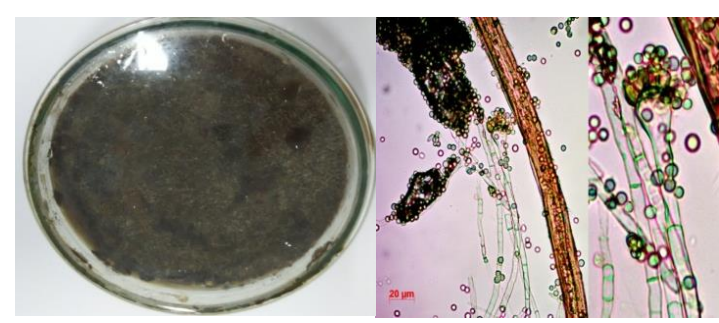

(a)

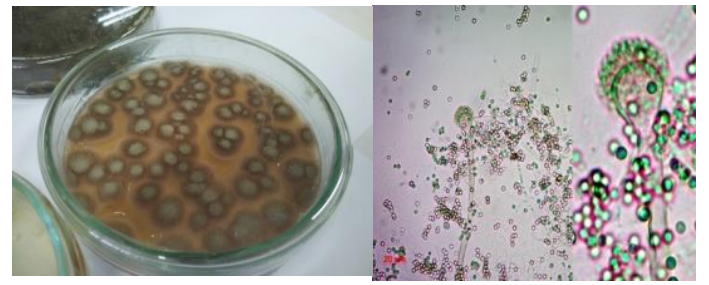

(b)

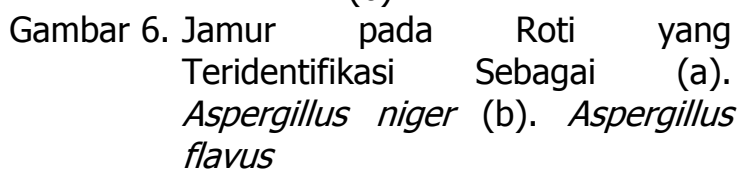


Keberadaan Penicillium pada roti sampel teridentifikasi berdasarkan beberapa ciri spesifik diantaranya adalah hifa septat, miselium bercabang, kepala yang membawa sterignmata berkelompok dan konidia berwarna hijau (Gambar 5). Seperti halnya Aspergillus dan Penicillium, keberadaan Mucor $s p$. juga teridentifikasi berdasarkan beberapa ciri spesifik diantaranya adalah hifa seperti benang putih; bagian tertentu tampak sporangium dan sporangiofor berupa titik-titik hitam seperti jarum pentul yang dapat diamati pada gambar 7.
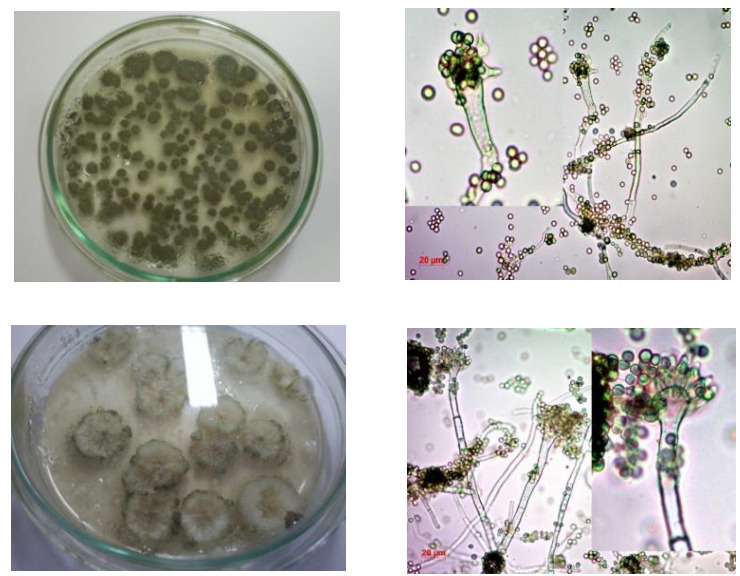

Gambar 7. Jamur pada Roti yang Teridentifikasi Sebagai Penicillium sp.

Selain menghambat pertumbuhan beberapa jenis jamur yang merusak roti, penambahan lambda karagenan juga mampu menunda waktu pertumbuhan jamur. Roti kontrol dan roti dengan penambahan lambda karagenan menunjukkan adanya pertumbuhan jamur pada hari ke-4 masa simpan. Selain keberadaan senyawa bioaktif tertentu yang bersifat antagonis terhadap jamur, kondisi ini berpotensi terkait dengan kemampuan karaginan dalam memperlambat perpindahan kelembapan menuju permukaan roti (Fennema, 1996; Sciarini et al., 2012), sehingga kadar air dipermukaan roti tidak meningkat dalam waktu singkat dan menunda terciptanya lingkungan yang mendukung pertumbuhan jamur. Fakta ini menunjukkan bahwa lambda karagenan selain mampu bertindak sebagai bread improver juga memiliki potensi sebagai pengawet alami pada roti.

\section{KESIMPULAN}

Berdasarkan hasil pengamatan dan pembahasan dapat ditarik beberapa kesimpulan sebagai berikut:
ISSN: 2443-1095

1 Kadar air roti yang ditambahkan lambda karaginan cenderung lebih stabil dibandingkan roti yang tidak ditambahkan karaginan.

2 Roti dengan penambahan lambda karaginan memiliki angka total jamur yang lebih rendah dibandingkan kontrol hingga pada hari ke 4 penyimpanan yaitu sebesar $4,255 \log \mathrm{cfu} / \mathrm{ml}$.

3 Roti dengan penambahan lambda karaginan memiliki angka total mikroba lebih rendah dibandingkan kontrol pada hari ke-3 pengyimpanan yaitu sebesar $8,556 \log \mathrm{cfu} / \mathrm{ml}$.

4 Roti dengan ataupun tanpa penambahan karaginan memiliki total coliform yang sangat rendah yaitu sebesar $<2,398$ log $\mathrm{cfu} / \mathrm{ml}$, karena dalam proses pembuatan roti setiap bahan ataupun pekerja bekerja secara aseptis.

5 Jenis jamur yang tumbuh pada roti dengan penambahan lambda karagenan adalah Aspergillus niger dan Aspergillus flavus

\section{DAFTAR PUSTAKA}

Ananingsih, K. dan Y. Wirawan, 2006. Optimasi Proses Produksi Tepung Karagenan (Processed Eucheuma Seaweed/PES) yang Diekstrak dari Eucheuma Cottonii dengan Penggunaan Berbagai Jenis Alkali dan Bleaching Agent. Skripsi Program Studi Teknologi Pangan. Fakultas Teknologi Pertanian. Universitas Katolik Soegijapranata. Semarang.

Ćuric, Duška; Novotni, Dubravka; Tusak, Dubravka; Bauman, Ingrid; Gabric, Domagoj, 2007. Gluten-Free Bread Production by the Corn Meal and Soybean Flour Extruded Blend Usage. Agriculturae Conspectus Scientificus University of Zagreb, Faculty of Food Technology and Biotechnology Vol. 72 No. 3 Hal. 227-232.

Dengate S. and Ruben A., 2002. Controlled trial of cumulative bahavioural effects of a common bread preservative. $J$. Paediatr. Child. Health. 38: 373-376.

Fardiaz, Srikandi. 1992.Mikrobiologi Pangan 1. PT Gramedia Pustaka Utama. Jakarta

Fardiaz, S., 1992. Petunjuk Laboratorium Mikrobiologi Pengolahan Pangan. Departemen Pendidikan dan Kebudayaan. Direktorat Jenderal Pendidikan Tinggi. Pusat Antar 
Universitas Pangan dan Gizi. Institut Pertanian Bogor. Bogor.

Fennema, 1976. Principle of Food Science I. Food Chemistry. Marckel Dekker Inc. New York.

Florian M. Ward, William H. Hanway, Richard B. Ward, 2006. Food Gums Functional Properties and applications In Handbook of Food Science, Technology, and Engineering Ed. Y.H.hu AB.i. Vol 3. Cpt 139. Pgs $139-11$ CRC Press. USA

Gaman, P. M. dan Sherrington, K.B., 1992. Ilmu Pangan, Pengantar Ilmu Pangan, Nutrisi dan Mikrobiologi. Gajah Mada University Press. Yogyakarta.

Ghanbari, M., dan J. Farmani, 2013. Influence of Hydrocolloids on Dough Properties and Quality of Barbari: An Iranian Leavened Flat Bread. J. Agr. Sci. Tech. 15: $545-555$.

Glicksman, M., 1983. Food Hydrocolloids, Volume II. CRC Press. Inc. New York

Hanafiah, 2002. Rancangan Percobaan Edisi Ke Tiga. Jakarta: Rajawali Press.

Kam, P. V., A. Bianchini, and L. B. Bullerman. RURALS: Review of Undergraduate Research in Agricultural and Life Sciences, Vol. 2 [2007], Iss. 1, Art.

Kurokawa, Y., Maekawa, A., Takahashi dan M. Hayasi, Y., 1990. Toxicity and Carcinogenicity of Potassium Bromate; A New Renal Carcinogen. Environ. Health Persp. 87:309-335.

Leon, A.E., Ribotta, P.D., Fernandez, C., Lanada, C.A., dan Beltramo, D.M., 2000. Interactions of different carrageenan isoforms and flour components in breadmaking. J. Food Agric. Food Chem. 48 (7): 2634-2638.

Matz, S. A., 1992. Bakery Technology and Engineering, 3th edition. Van Nostrand Reinhold. Texas.

Mudjajanto, S.E. dan L.N. Yulianti, 2004. Membuat Aneka Roti. Penerbit Swadaya. Jakarta.

Parsons, J.L. dan Chipman, J.K., 2000.The role of glutathione in DNA damage by potassium bromate in vitro. Mutagenesis.15(4):311-316.

Rahmadi, E. L. dan Bendatu, L. Y., 2015. Studi Kelayakan Pendirian Perusahaan OPP di
Kota Sidoarjo. Jurnal Titra. 3(2): 123128.

Rehman, S dan A. Mudassar, 2003. Effect of Carboxxy methyl Cellulose and Carrageenan gum on the Shelf life of Bread. Pak J. Food Science 13(1): 4952.

Rodge, A.B, Sonkamble, S.M., Salve, R.V., dan Hasmi, S.I., 2012. Effect of hydrocolloid (guar gum) Incorcopration on the Quality Characteristics of Bread. J Food Process Techno/ 3:2.

Rosell, C. M., Rojas, J. A. dan Benedito, C., 2001. Influence of Hydrocolloids on Dough Rheology and Bread Quality. Food Hydrocol 15: 75-81.

Sciarini, L. S., Ribotta, P. D., Leon, A. E., dan Perez G. T. 2012. Incorporation of Several Additives into Gluten Free Breads: Effect on Dough Properties and Bread Quality, J. Food Eng., 111: 590597.

Selomulyo, V. O. dan Zhou, W., 2006. Frozen Bread Dough: Affects of Freezing Storage and Dough Improvers. Journal of Cereal Science.

September, C., 2007. The Effect of enzymes, gums and proteins on the water absorption, loaf volume and shelf life of bread. Master Thesis. Johannesburg Oct. University.

Setyo E, Noor L, 2004. Membuat Aneka Roti. Jakarta : Penebar Swadaya

Suptijah, 2004. Rumput Laut: Prospek dan Tantangannya.

http://tumoutou.net/702_04212/pipih_s uptijah.htm. (Diakses pada 15 Maret 2016).

Syarbini, H., 2013. A-Z Bakery. PT. Tiga Serangkai Pustaka Mandiri. Semarang.

Uchida, H. A., Sugiyama, H., Kanehisa, S., Harada, K., Fujiwara, K. dan Ono, T., 2006. An elderly patient with severe acute renal failure due to sodium bromated intoxication. Intern Med 45: 151-154.

Venugopal, V., 2008. Marine Products for Healthcare: Functional and Bioactive Nutraceutical Compounds from the Ocean. CRC Press. NW Boca Rato FL. 
Winarno, F.G dan Jenie, B.S.L, 1982. Kerusakan Bahan Pangan dan Cara Pencegahannya. Pusat Penelitian dan Pengembangan Teknologi Pangan. Institut Pertanian Bogor. Ghalia Indonesia. Jakarta.
Winarno, F.G., 1994. Bahan Tambahan Untuk Makanan dan Kontaminan. Pusat Sinar Harapan. Jakarta.

Winarno, F.G., 1983. Gizi Pangan, Teknologi dan Konsumsi. Gramedia Pustaka Utama. Jakarta 